\title{
一対の内湾曲線で薄肉・厚肉に領域分割された部分円筒シェルの構造的特徵 STRUCTURAL CHARACTERISTICS OF THE PARTIAL CIRCULAR CYLINDER
PARTITIONED INTO THICK AND THIN SHELLS BY A PAIR OF CONCAVE CURVES
}

\author{
高 垣 利 $*^{*}$
}

Toshio TAKAGAKI

\begin{abstract}
Herein investigated is a partial circular cylinder, which is partitioned by a pair of concave curves into an inner thick shell zone with both fixed boundaries parallel to the generator, and two outer thin shell zones with free edges. It is found that, given a method of distributing suitable thicknesses to each shell zone, the outer thin shell zones in membrane stress states are cantilever-supported by the inner thick shell zone treated as an arch of which breadth and height vary in the circular direction. Each zone of the seemingly complicated shell is solved, analytically and sequentially without difficulty. Moreover, this method introduced here is confirmed convenient for assembling proper shell thicknesses in order to cover a large space economically.
\end{abstract}

\section{Keywords:Circular Cylindrical Shell,Membrane Stress, Circular Arch,Ring,Differential Equation,Finite Element Method} 円筒シェル, 膜応力, 円弧アーチ, リング, 微分方程式, 有限要素法

1 はじめに

\section{1 背景と動機}

一対の母線方向直線と一対の円弧を境界とする部分円筒シェル （ロングシェル）は、1940 年代から屋根として主に母線方向に梁形 式で架構することが実用化され、1952 年発行の ASCE 設計手順書 1) 以後も、多くの綿密な研究が行われて来た ${ }^{2-5)}$ 。

ただしロングシェルは、形状的に面内応力未知数の数と境界条件 の数が一致しないため、膜応力状態を保つのが困難であった ${ }^{1-3)}$ 。 このため、面外応力を加えて境界条件を満足させる必要があり、円 弧方向境界には妻壁やリブアーチを、母線方向境界には裾梁を設け て、境界付近の面外応力を処理する設計がなされてきた ${ }^{5) 。 ~}$

筆者は既報 ${ }^{8)}$ において、円筒シェルの釣り合いと応力ー歪一変位 関係を表す、古典的な連立偏微分方程式 $2,3,7)$ に対する考察から、あ る数学的な条件のもと切り出された形状を持つ円筒シェルが、片持 ち形式で「理想的に」支持される場合に膜応力状態にあること、及 び、例題による数值解析との比較から、シェルの厚みが薄い場合、 「現実的な（固定の）」支持条件においても、局所的応力集中を除い ては膜応力状態が保たれることを示した。

本論文では、両側の薄肉円筒シェル領域が、既報 ${ }^{8)}$ 例題に示した 数学的条件を満たした形状を持ち、膜応力状態を保ったまま、一対 の内湾曲線を外縁とし、幅と厚みが変化する変断面の固定アーチと みなせる、厚肉円筒シェル領域に片持ち支持される構造を考える。

このように厚肉シェル領域をアーチとみなせることにより、全体 としてのの複雑な板厚分布にもかかわらず、板厚や形状についての パラメーターを残したまま、本構造は解析的に連続的に解ける。

本構造は、上述の既報 ${ }^{8)}$ 「筒カットアウト片持ちシェル構造」 の拡張であり、シェルらしい薄い自由辺を持つ片持ちシェルを、 その膜応力状態を保証できる境界形状を持つアーチで支持している。
これにより、できるだけ薄肉領域を広くするよう領域の割り振り をすれば、内部に制約のない開放的な大空間が材料節約面から経済 的に得られることを、パラメトリックな手法をもって検証する。

\section{2 論旨}

以下の流れにより、論考を進める。

(1) 円弧方向座標 $\varphi$ に従って幅と厚みが変化する、変断面円弧アー チの理論式（連立常微分方程式）を、円筒シェルの一般式から直接 的に誘導する。

(2) ともにシェルの一般式から導かれる、既報 ${ }^{8)}$ の薄肉片持ち膜応 力理論と上記変断面アーチ理論には、円弧方向変位 $\mathrm{V}$ 一法線方向変 位 $\mathrm{W}$ 関係式に類似性があり、これにより片持ちシェル（薄肉シェル 領域）と変断面アーチ（厚肉シェル領域）の境界での変位の連続性 を数式を用いて評価する。

(3) アーチに適切な剛性分布を与える簡単な例として、厚肉シェル領 域の幅と厚みを $\varphi$ が変化しても断面積は不変とし、薄肉シェル領域 が膜応力理論で、厚肉シェル領域がアーチ理論で独立して連続的に 解析出来るよう、十分な厚肉・薄肉のシェル板厚差を設定する。

(4) シェル体積をシェル展開面積で除した值（平均板厚）は常に一定 という条件の下で、厚肉・薄肉シェルの形状に関する、いくつかの パラメーターを残したまま、薄肉シェルに対する膜応力解析に続い て、変断面アーチの連立常微分方程式を解く。

(5) 解析の結果得られた応力・変形のパラメトリックな考察から、上 記に述べた板厚設定方法や解析方法が、適切であることを確認する。

(6) 上記考察からの典型的と判断される例題に対し、筆者開発の既 報 ${ }^{8)}$ に示す有限要素法を、厚肉シェルにも適用可能なように、ひず み一変位関係式を Donnell 式から Flügge 式に拡張し、数值解析を 行い、結果を理論解と比較し、確認する。 
2 シェルの概要

\section{1 シェルの形状と境界条件}

対象とする部分円筒シェルの立体的な概要を Fig.1に、形状及び 境界条件の詳細を Fig.2、円筒を展開し、無次元化した $\xi(:$ :線方向 generator direction $)-\varphi$ (円弧方向 circular direction) 平面上に示す。

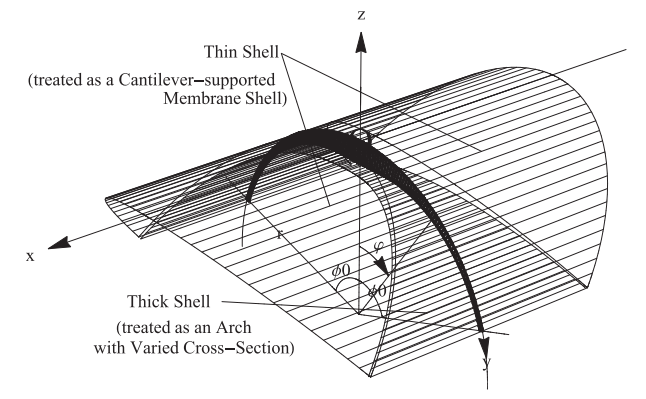

Fig.1 Shell shape on 3D space

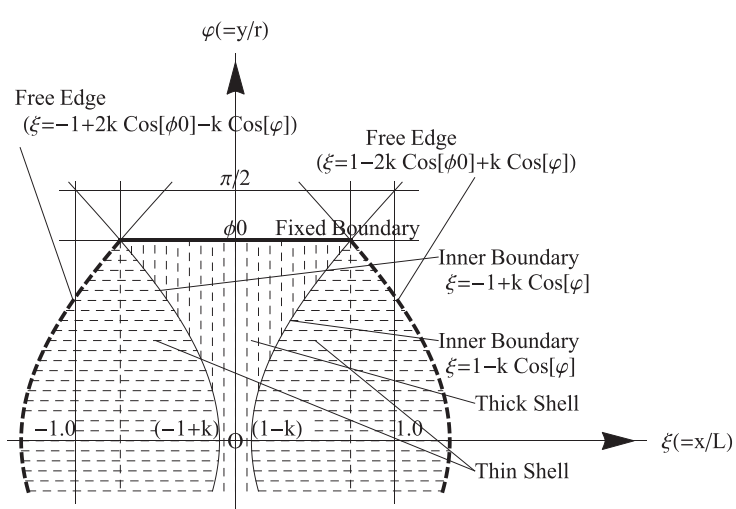

Fig.2 Shell shape on developed $(\xi-\varphi)$ plane

$\xi-\varphi$ 平面は、円筒の半径 $r$ と、薄肉・厚肉の境界曲線 (内部境界曲 線）を $\varphi= \pm \pi / 2$ に延長した母線方向辺長 $2 L$ を使って、 $\xi=x / L$ 、 $\varphi=y / r$ のように、長さのある $x-y$ 平面を無次元化したものであ る。以後の論考は $x-\varphi$ 系を基本とするが、計算は $x-y$ 系で行う。 $\xi$ は本項、無次元化平面でのシェル形状説明に限って使用する。 形状と荷重の対称性を考慮して、 $x$ の正側の象限を対象に行う。

a) 展開平面上のシェル形状

シェルは $\xi 、 \varphi$ 両軸に関して対称であり、開角を $2 \phi_{0} 、 L$ と半径 $r$ の比を $\alpha$ 、つまり $(L=\alpha r)$ と表す。定義域は、円筒シェルの特徵 がよくわかるよう、 $\pi / 3 \leq \phi_{0} \leq \pi / 2 、 1 \leq \alpha \leq 2$ とする。

内部境界曲線は、 $\xi= \pm(1-k \cos (\varphi))$ で表される余弦曲線を 用いる。外部自由境界は、薄肉シェル自体も対称形状となるよう、 $\xi= \pm\left(1-2 k \cos \left(\phi_{0}\right)+k \cos (\varphi)\right)$ とする。

ここに $k$ の定義域は $0 \leq k \leq 1$ であり、 $k=0$ ではシェルは厚肉 領域のみの等厚で水平投影形状が矩形となり、 $k=1$ (かつ $\alpha=1$ 、 $\left.\phi_{0}=\pi / 2\right)$ では、水平投影形状が円である薄肉シェル (既報 ${ }^{8)}$ の例 題） 2 つが厚肉シェルと原点 $\mathrm{O}$ で接する形状となる。 $k$ と $\alpha$ は、独 立したパラメーターである。

b) シェルの厚さ

薄肉シェルの厚み $t_{b}$ はシェル内で一定とする。

厚肉シェルの厚み $t$ は、 $\varphi$ が一定での断面の面積 $A$ （アーチの
断面積）が弧全長に渡り一定となるよう中央に向かって増加する、 $\varphi= \pm \pi / 2$ での厚みを $t_{a}$ として、 $t=t_{a} /(1-k \cos (\varphi))$ と表され るものとなる。( $A=t_{a} L=t_{a} \alpha r=$ const. $)$

c) 薄肉・厚肉のシェル板厚関係式

第一象限を考えると、厚肉シェルの面積 $S_{a}$ と薄肉シェルの面積 $S_{b}$ は、 $S_{a}=L r\left(\phi_{0}-k \sin \left(\phi_{0}\right)\right) 、 S_{b}=2 k L r\left(\sin \left(\phi_{0}\right)-\phi_{0} \cos \left(\phi_{0}\right)\right)$ 、 $S_{a}+S_{b}=L r\left(\phi_{0}-2 k \phi_{0} \cos \left(\phi_{0}\right)+k \sin \left(\phi_{0}\right)\right)$ である。

厚肉シェルの体積 $V_{a}=L r t_{a} \phi_{0}$ に対し、薄肉シェルの体積 $V_{b}$ は, $V_{b}=S_{b} t_{b}=2 k L r t_{b}\left(\sin \left(\phi_{0}\right)-\phi_{0} \cos \left(\phi_{0}\right)\right)$ となる。

コンクリート量が一定となるよう、平均した板厚を薄肉シェルの 厚み $t_{b}$ の $n$ 倍として、 $n t_{b}\left(S_{a}+S_{b}\right)=V_{a}+V_{b}$ を解くと、

$t_{a} / t_{b}=n\left(1-2 k \cos \left(\phi_{0}\right)+\frac{k \sin \left(\phi_{0}\right)}{\phi_{0}}\right)+2 k\left(\cos \left(\phi_{0}\right)-\frac{\sin \left(\phi_{0}\right)}{\phi_{0}}\right)$

ここでは $t_{a}$ を、曲げを受ける部材との想定から $r / 50$ 程度、 $t_{b}$ を、 膜応力状態にある部材との想定から $r / 200$ 程度と考え、その比から $n=4$ と設定して、シェル板厚関係 $\beta=t_{a} / t_{b}$ を以下とする。

$\beta=t_{a} / t_{b}=\frac{2 k \sin \left(\phi_{0}\right)}{\phi_{0}}-6 k \cos \left(\phi_{0}\right)+4$

$\beta$ は $k$ に応じ、 $\phi_{0}=\pi / 3$ で $4 \sim 2.7 、 \phi_{0}=\pi / 2$ で $4 \sim 5.3$ であ る。 $k=1$ では原点 $\mathrm{O}$ で幅 0 、厚み無限大だが、面積一定となる。

\section{2 シェルの荷重}

シェルの単位面積当たりの荷重は、上記展開平面のシェルの定義 域内でシェル面内の $\mathrm{x}$ 方向、 $\varphi$ 方向、面外の $\mathrm{z}$ 方向に、それぞれ、 $p_{x}(x, \varphi) 、 p_{\varphi}(x, \varphi) 、 p_{z}(x, \varphi)$ と表現する。

本論文では、自重と母線直角方向水平力（地震力：震度 $K=1$ ) の 2 種類の荷重を取り上げるが、これらの重ね合わせとなる荷重も 同じように取り扱える。シェルの単位体積あたり質量を $\gamma$ 、厚みを $\mathrm{t}$ として、 $p_{x}(x, \varphi) 、 p_{\varphi}(x, \varphi) 、 p_{z}(x, \varphi)$ は以下とする。（自重）: $p_{x}(x, \varphi)=0, p_{\varphi}(x, \varphi)=\gamma \mathrm{t} \sin (\varphi), p_{z}(x, \varphi)=\gamma(-\mathrm{t}) \cos (\varphi)$ （地震 : 母線直角方向水平力（震度 $K=1 ）$ ）: $p_{x}(x, \varphi)=0, p_{\varphi}(x, \varphi)=\gamma \mathrm{t} \cos (\varphi), p_{z}(x, \varphi)=\gamma \mathrm{t} \sin (\varphi)$

母線方向水平力は、形状的 $(1 \leq \alpha \leq 2)$ に、せん断力を主とする 面内力として処理され、クリティカルとならないので、検討を略す。

\section{3 薄肉シェル領域の解析}

本節 $3.1 、 3.2$ は既報 ${ }^{8)}$ と重複するが、本稿完結性のため載せる。

\section{1 円筒シェルの釣り合いー般式}

円筒シェル微小要素の合応力釣り合い式は以下のとおりである。 なお、関数の右上サフィクス $(\mathrm{m}, \mathrm{n})$ は、関数を一番目の変数で $\mathrm{m}$ 階、二番目の変数で $\mathrm{n}$ 階偏微分することを示す。(Fig.3 参照。)

（母線方向合応力の釣り合い式）

$\frac{\mathrm{N} \varphi \mathrm{x}^{(0,1)}(x, \varphi)}{r}+\mathrm{Nx}^{(1,0)}(x, \varphi)+p_{x}(x, \varphi)=0$

（円周方向合応力の釣り合い式）

$\frac{\mathrm{N} \varphi^{(0,1)}(x, \varphi)}{r}+\mathrm{Nx} \varphi^{(1,0)}(x, \varphi)+p_{\varphi}(x, \varphi)+\frac{\mathrm{Q} \varphi(x, \varphi)}{r}=0$

（法線方向合応力の釣り合い式）

$-\frac{\mathrm{N} \varphi(x, \varphi)}{r}+p_{z}(x, \varphi)+\frac{\mathrm{Q} \varphi^{(0,1)}(x, \varphi)}{r}+\mathrm{Qx}^{(1,0)}(x, \varphi)=0$ 
$\mathrm{z}$ 軸周りのモーメントの釣り合いから $\mathrm{Nx} \varphi$ は $\mathrm{N} \varphi \mathrm{x}$ に等しい。 円筒シェル微小片の合モーメント釣り合い式は、以下である。

(Fig.4 参照、図中のモーメントは二重矢印軸回転方向を正とする。)

（母線方向合モーメントの釣り合い式）

$\frac{\mathrm{M} \varphi^{(0,1)}(x, \varphi)}{r}+\operatorname{Mx} \varphi^{(1,0)}(x, \varphi)-\mathrm{Q} \varphi(x, \varphi)=0$

（円周方向合モーメントの釣り合い式）

$\frac{\mathrm{M} \varphi \mathrm{x}^{(0,1)}(x, \varphi)}{r}+\mathrm{Mx}^{(1,0)}(x, \varphi)-\mathrm{Qx}(x, \varphi)=0$

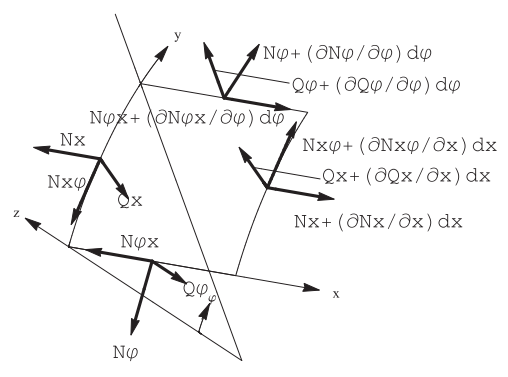

Fig.3 Stresses around a cylindrical shell element

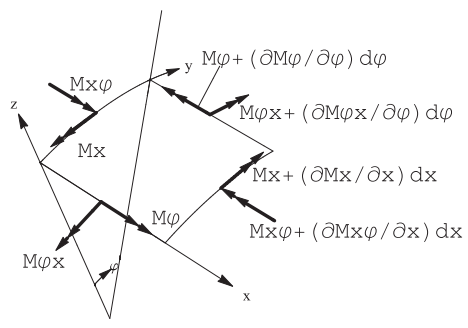

Fig.4 Bending moments around a cylindrical shell element

\section{2 薄肉片持ちシェルの膜応力}

前項釣り合い式の曲げに起因する項 $\mathrm{Mx}, \mathrm{M} \varphi, \mathrm{Mx} \varphi, \mathrm{M} \varphi \mathrm{x}, \mathrm{Qx}, \mathrm{Q} \varphi$ を無視することにより、面内力だけで外力と釣り合う、以下 (6)、 (7)、(8) の膜応力の釣り合い式が得られる。

$\mathrm{N} \varphi(x, \varphi)=r p_{z}(x, \varphi)$

$\mathrm{N} \varphi \mathrm{x}^{(1,0)}(x, \varphi)+p_{\varphi}(x, \varphi)+\mathrm{N} \varphi^{(0,1)}(x, \varphi) / r=0$

$\mathrm{N} \varphi \mathrm{x}^{(0,1)}(x, \varphi) / r+\mathrm{Nx}^{(1,0)}(x, \varphi)+p_{x}(x, \varphi)=0$

(6) より直接的に $\mathrm{N} \varphi(x, \varphi)$ が (自重) $\mathrm{N} \varphi(\xi, \varphi)=\gamma(-r) t_{b} \cos (\varphi)$ (地震) $\mathrm{N} \varphi(\xi, \varphi)=\gamma r t_{b} \sin (\varphi)$ と求まり、これを (7)、(8) に代入 して積分し、自由辺上での境界条件（応力境界）を満足するような $\mathrm{N} \varphi \mathrm{x}(x, \varphi) 、 \mathrm{Nx}(x, \varphi)$ を求める手順は既報 ${ }^{8)}$ に示すとおりであり、 自由辺を表す数式 $f(y)=\alpha r\left(1-2 k \cos \left(\phi_{0}\right)+k \cos (y / r)\right)$ を代入 して直接的に得られる。

\section{3 薄肉片持ちシェルの変形}

面内力を受ける弾性平板同様のひずみ一応力関係式と、薄肉を仮 定した円筒シェルの Donnell ひずみー変位関係式 7) を、膜応力状態 を考慮して（中立点に部材断面の面積が集中していると考えて）簡 略化し、以下の応力ー変位関係式を得る。
ここに $\mathrm{E}$ ヤング係数、 $\nu$ ポアソン比。

$u^{(1,0)}(x, \varphi)=\frac{\mathrm{Nx}(x, \varphi)-\nu \mathrm{N} \varphi(x, \varphi)}{\mathrm{E} t_{b}}$

$v^{(1,0)}(x, \varphi)=\frac{2(\nu+1) \mathrm{N} \varphi \mathrm{x}(x, \varphi)}{\mathrm{E} t_{b}}-u^{(0,1)}(x, \varphi) / r$

$w(x, \varphi)=r\left(\frac{\mathrm{N} \varphi(x, \varphi)-\nu \mathrm{Nx}(x, \varphi)}{\mathrm{E} t_{b}}-v^{(0,1)}(x, \varphi) / r\right)$

応力 $\mathrm{Nx}(x, \varphi), \mathrm{N} \varphi(x, \varphi) 、 \mathrm{~N} \varphi \mathrm{x}(x, \varphi)$ は既知であるので、(9)、(10) の順に積分を実行し、支持辺における, 変位 $u(x, \varphi) 、 v(x, \varphi)$ の境界 条件を満たすよう、積分定数を決定していくことで、シェルの変形 $u(x, \varphi), v(x, \varphi), w(x, \varphi)$ が求まる。

式 (11) から判るように、 $w(x, \varphi)$ は、 $u(x, \varphi), v(x, \varphi)$ が決定され ると、自動的に決定される。(上記 3 つの連立偏微分方程式のうち、 決定可能な積分定数の数が 2 つであるという理由による。)

式 (9) を $x$ で積分し、支持辺上で $x$ 方向変位 $u=0$ を満たすよ う、積分定数を決定した、 $x$ 方向変位を $u_{0}(x, \varphi)$ とする。

式 $(10)$ の $u(x, \varphi)$ に $u_{0}(x, \varphi)$ を代入して $x$ で積分し、支持辺上で $\varphi$ 方向変位 $v=0$ を満たすよう、積分定数を決定した、 $\varphi$ 方向変位 を $v_{0}(x, \varphi)$ とする。(つまり、 $\left.v_{0}(\alpha r(1-k \cos (\varphi)), \varphi)=0\right)$

ここでは支持辺上で $u=0 、 v=0$ としているが、偏微分方程式 (9)、(10) は支持辺上の $u 、 v$ がどのように指定されてもそれを満た すことが可能な形をしている。厚肉シェルを表す円弧アーチの $\varphi$ 方 向変位 $V(\varphi)$ は、まさにこの支持辺が指定する変位である。よって、 薄肉シェルの領域内の $\varphi$ 方向変位 $v(x, \varphi)$ は、 $v_{0}(x, \varphi)$ に $V(\varphi)$ を 付け加えて、 $v(x, \varphi)=v_{0}(x, \varphi)+V(\varphi)$ である。

$v(x, \varphi)=v_{0}(x, \varphi)+V(\varphi)$ を、式 (11) に代入して、

$w(x, \varphi)=r\left(\frac{\mathrm{N} \varphi(x, \varphi)-\nu \mathrm{Nx}(x, \varphi)}{\mathrm{E} t_{b}}-v_{0}^{(0,1)}(x, \varphi) / r\right)-d V(\varphi) / d \varphi$

既報 ${ }^{8)}$ において、支持辺で母線方向変位 $u$ と円弧方向変位 $v$ を固 定した上で、膜応力状態を可能とするよう強制された法線方向変位 $w$ を採ることを理想的支持と呼んだが、そのように支持されたシェ ルの $z$ 方向変位 $w_{0}(x, \varphi)$ は、

$w_{0}(x, \varphi)=r\left(\frac{\mathrm{N} \varphi(x, \varphi)-\nu \mathrm{Nx}(x, \varphi)}{\mathrm{E} t_{b}}-v_{0}^{(0,1)}(x, \varphi) / r\right)$

式 $(12)(13)$ から $\quad w(x, \varphi)=w_{0}(x, \varphi)-d V(\varphi) / d \varphi$

次節 4.3 項の式 (22) に示すように、円弧アーチとしての厚肉シェ ルの $\mathrm{z}$ 方向変位を $W(\varphi)$ と表せば、 $W(\varphi)=-d V(\varphi) / d \varphi$ なので、

$w(x, \varphi)=w_{0}(x, \varphi)+W(\varphi)$

内部境界曲線上での薄肉シェルと円弧アーチとして取り扱う厚肉 シェルの $\mathrm{z}$ 方向変位の差は $w_{0}(\alpha r(1-k \cos (\varphi)), \varphi)$ となる。これ は理想的支持のため要求される支持境界上の強制変位であるが、既 報 ${ }^{8)}$ に示したように薄肉シェルでは、それを無視しても、局所以外 の膜応力状態は保たれる。

なお、 $u_{0}(x, \varphi) 、 v_{0}(x, \varphi) 、 w_{0}(x, \varphi)$ は、既報 ${ }^{8)}$ に一般化した数式を 示しており、それに支持境界の方程式 $g(y)=\alpha r(1-k \cos (y / r))$ 、 自由境界の方程式 $f(y)=\alpha r\left(1-2 k \cos \left(\phi_{0}\right)+k \cos (y / r)\right)$ を代入 すれば得られる。 
3.4 薄肉シェルから厚肉シェルヘの作用力

内部境界曲線 $x=\alpha r(1-k \cos (y / r))$ の単位法線ベクトル $\nu_{b}$ は

$\nu_{b}=\left\{-\frac{1}{\sqrt{\alpha^{2} k^{2} \sin ^{2}(\varphi)+1}}, \frac{\alpha k \sin (\varphi)}{\sqrt{\alpha^{2} k^{2} \sin ^{2}(\varphi)+1}}\right\}$

内部境界曲線上の応力テンソル $N_{b}=$

$\left(\begin{array}{cc}\mathrm{Nx}(\alpha r(1-k \cos (\varphi), \varphi)) & \mathrm{N} \varphi \mathrm{x}(\alpha r(1-k \cos (\varphi)), \varphi) \\ \mathrm{N} \varphi \mathrm{x}(\alpha r(1-k \cos (\varphi), \varphi)) & \mathrm{N} \varphi(\alpha r(1-k \cos (\varphi), \varphi))\end{array}\right)$

ここにテンソルの要素、 $\mathrm{N} \varphi(\alpha r(1-k \cos (\varphi)), \varphi)$ は、

(自重) $-\gamma r t_{b} \cos (\varphi)$ 、(地震) $\gamma r t_{b} \sin (\varphi)$ であり、

$\mathrm{N} \varphi \mathrm{x}(\alpha r(1-k \cos (\varphi)), \varphi)$ は、以下となる。

(自重) $\alpha \gamma k r t_{b} \sin (\varphi)\left(5 \cos (\varphi)-4 \cos \left(\phi_{0}\right)\right)$

(地震) $\alpha \gamma k r t_{b}\left(-4 \cos (\varphi) \cos \left(\phi_{0}\right)-\sin ^{2}(\varphi)+4 \cos ^{2}(\varphi)\right)$

Caushy の公式より、応力ベクトル $\mathrm{T}=N_{b} \cdot \nu_{b}$ なので $\mathrm{T}=$ $\{\mathrm{Tx}, \mathrm{T} \varphi\}$ と表せば、線積分経路長さ $d s=\sqrt{\alpha^{2} k^{2} \sin ^{2}(\varphi)+1} d y$ に 注意して、変断面アーチとして取り扱う厚肉シェルに作用する薄肉 シェルからの円弧方向荷重 $\mathrm{F} \varphi=-\mathrm{T} \varphi=$

(自重) $2 \alpha \gamma k r t_{b} \sin (\varphi)(3 \cos (\varphi)-2 \cos (\phi 0))$

(地震) $-2 \alpha \gamma k r t_{b}\left(2 \cos (\varphi) \cos (\phi 0)+\sin ^{2}(\varphi)-2 \cos ^{2}(\varphi)\right)$

\section{4 厚肉シェル領域の解析}

\section{1 厚肉シェル領域を アーチとみなすことの妥当性と意義}

$k=0$ の場合、水平投影形状が矩形の等厚（厚肉）シェルであり、 Young 係数 $\mathrm{E}$ を $\mathrm{E} /\left(1-\nu^{2}\right)$ に修正して単純に、厚みに比して幅の 大きい断面を持つ円弧アーチとみなすことが出来る ${ }^{6) 。}$

一方、 $k=1$ の場合の厚肉シェル領域は、中間部での $x$ 方向の材 長が小さく、 $x$ 方向材長の大きい端部では固定であるので、自重や 母線直角方向水平力という荷重については、 $\varphi$ 方向や $z$ 方向の変形 に比べて、 $x$ 方向の変形は極めて小さい。これにより、 $x$ 方向の変形 を無視して（ $\varphi$ 一定での肉厚シェルの断面の形状は、荷重によって 変化しないとして)、厚肉シェル領域を円弧アーチとみなす。

その間 $0<k<1$ は、上記両端の補間状態と考え、同様に厚肉 シェル領域を円弧アーチとみなす。

厚肉シェル領域を円弧アーチとみなすことの意義は、本構造が、 全体として複雑な板厚分布にもかかわらず、板厚や形状についての パラメーターを残したまま、解析的に解けることにある。

\section{2 円弧アーチの釣り合い式}

アーチ構造が $\varphi$ 方向のみの 1 次元問題であること、すなわち $x$ 方 向の構造諸量がすべて定数であることを考慮し、3.1 項に示す円筒 シェルの釣り合い一般式 $(2) \sim(4)$ の $x$ に関する微分を示す項をすべ てゼロとし、以下の $\left(2^{*}\right) \sim\left(4^{*}\right)$ を得る。

$$
\begin{aligned}
& \frac{\mathrm{N} \varphi^{(0,1)}(x, \varphi)}{r}+p_{\varphi}(x, \varphi)+\frac{\mathrm{Q} \varphi(x, \varphi)}{r}=0 \\
& -\frac{\mathrm{N} \varphi(x, \varphi)}{r}+p_{z}(x, \varphi)+\frac{\mathrm{Q} \varphi^{(0,1)}(x, \varphi)}{r}=0 \\
& \frac{\mathrm{M} \varphi^{(0,1)}(x, \varphi)}{r}-\mathrm{Q} \varphi(x, \varphi)=0
\end{aligned}
$$

式 $\left(4^{*}\right)$ より得られる $\mathrm{Q} \varphi(x, \varphi)=\mathrm{M} \varphi^{(0,1)}(x, \varphi) / r$ を $\left(2^{*}\right) 、\left(3^{*}\right)$ 式に代入して $\mathrm{Q} \varphi(x, \varphi)$ を消去し、応力を $\varphi$ のみの関数として書き 表すと以下のアーチの釣り合い式が得られる。

$\frac{\mathrm{M}^{\prime}(\varphi)}{r^{2}}+\frac{\mathrm{N}^{\prime}(\varphi)}{r}+p_{\varphi}(\varphi)=0$

$\frac{\mathrm{M}^{\prime \prime}(\varphi)}{r^{2}}-\frac{\mathrm{N}(\varphi)}{r}+p_{z}(\varphi)=0$

関数の右上はダッシュは、関数を変数 $\varphi$ で微分することを示す。

\section{3 円弧アーチの応力変位関係式}

円筒シェルの Flügge 理論による応力 $\mathrm{N} \varphi(x, \varphi) 、 \mathrm{M} \varphi(x, \varphi)$ の変位 との関係式は、以下である。

$$
\begin{aligned}
\mathrm{N} \varphi(x, \varphi) & =\frac{\mathrm{E} t}{1-\nu^{2}}\left(\frac{v^{(0,1)}(x, \varphi)}{r}+\frac{w(x, \varphi)}{r}+\nu u^{(1,0)}(x, \varphi)\right) \\
& +\frac{\mathrm{E} t^{3}}{12\left(1-\nu^{2}\right) r^{3}}\left(w^{(0,2)}(x, \varphi)+w(x, \varphi)\right)
\end{aligned}
$$

$\mathrm{M} \varphi(x, \varphi)=-\frac{\mathrm{E} t^{3}}{12\left(1-\nu^{2}\right)}\left(\frac{w^{(0,2)}(x, \varphi)}{r^{2}}+\frac{w(x, \varphi)}{r^{2}}+\nu w^{(2,0)}(x, \varphi)\right)$

式 $\left(5^{*}\right)$ と式 $\left(6^{*}\right)$ の $x$ に関する微分の項を無視する。さらに式 $\left(5^{*}\right)$ に対し、Donnell 理論 ${ }^{7)}$ による簡略化により最後の項を無視 し、さらに Timoshenko の仮定 ${ }^{6)}$ により、当関係式についての軸力 $\mathrm{N} \varphi$ の影響を無視して、左辺をゼロとする。（以上の簡略化の妥当性 を付録（リングの例題）にて検証している。）これにより、 $v(x, \varphi)$ 、 $w(x, \varphi)$ を $\varphi$ のの関数、 $\mathrm{V}(\varphi) 、 \mathrm{~W}(\varphi)$ で書き表す。

$0=\frac{V^{\prime}(\varphi)}{r}+\frac{W(\varphi)}{r}$

$\mathrm{M}(\varphi)=-\frac{\mathrm{E} t^{3}}{12\left(1-\nu^{2}\right)}\left(\frac{W^{\prime \prime}(\varphi)}{r^{2}}+\frac{W(\varphi)}{r^{2}}\right)$

\section{4 変断面円弧アーチの曲げモーメント・法線方向変位関係式}

4.2 項及び 4.3 項の微分方程式は、単位幅について構成されている ので、適用する変断面に合わせて修正する必要がある。ただし、断 面性能に関係しない、(20)(21)(22) はそのまま成立する。

アーチの幅 $B(\varphi)$ 、厚さ $t(\varphi)$ は、 $B(\varphi)=\alpha r(1-k \cos (\varphi))$ 、

$t(\varphi)=t_{a} /(1-k \cos (\varphi))$ なので、断面二次モーメント $I(\varphi)$ は、

$I(\varphi)=(B(\varphi))(t(\varphi))^{3} / 12=\alpha r\left(t_{a}\right)^{3} /\left(12(1-k \cos (\varphi))^{2}\right)$ である。

ここでは、幅広の断面を想定した Young 係数の増大 $E /\left(1-\nu^{2}\right)$ は用いず $E$ のままとし、式 (23) は下式 $(24)$ に置き換える。

$\frac{\mathrm{W}^{\prime \prime}(\varphi)}{r^{2}}+\frac{\mathrm{W}(\varphi)}{r^{2}}=-\frac{12 \mathrm{M}(\varphi)(1-k \cos (\varphi))^{2}}{\alpha \operatorname{Er}\left(t_{a}\right)^{3}}$

\section{5 変断面円弧アーチの解法}

円弧アーチの解法としては、面外変位の高次の微分方程式に余関 数法を適用するもの 10$) 、 2$ 次元問題に応力関数を適用するもの ${ }^{9)}$ があるが、幅と厚みが変化する当変断面アーチには適用できない。

ここでは変断面円弧アーチの応力 $\mathrm{N}(\varphi) 、 \mathrm{M}(\varphi)$ と変形 $\mathrm{W}(\varphi)$ 、 $\mathrm{V}(\varphi)$ を、式 $(24)$ に示す、アーチの断面（ $\varphi$ が一定の厚肉シェルの 断面）の断面 2 次モーメントが $\varphi$ の関数であることに注意して、式 (20)、(21)、(22)、(24) の定数係数の常微分方程式を、以下の手順で 解くことにより得る。(詳細は付録を参照。) 
a) まず式 $(20)$ をもう一度微分して、式 $(21)$ と辺々を引き、 $\mathrm{N}(\varphi)$ の 2 階の微分方程式を定数変化法で解く。 $\mathrm{N}(\varphi)$ は 2 個の未定（積 分）定数を含む形で得られる。

b) 上記の解 $\mathrm{N}(\varphi)$ をもう一度微分して式 $(21)$ に代入して、 $\mathrm{M}(\varphi)$ の 1 階の微分方程式を得る。これを積分して計 3 個の未定定数を含 んだ、 $\mathrm{M}(\varphi)$ を得る。

c) さらに上記の解 $\mathrm{M}(\varphi)$ を、式 $(24)$ に代入して、W $(\varphi)$ につい ての 2 階の微分方程式を定数変化法で解く。これにより、W $(\varphi)$ は 計 5 個の未定定数を含んで得られる。

d) 最後に上記の解 $\mathrm{W}(\varphi)$ 式 $(21)$ に代入した、 $\mathrm{V}(\varphi)$ の 1 階の微 分方程式を積分して、計 6 個の未定定数を含む $\mathrm{V}(\varphi)$ を得る。

e) 以上計 6 個の未定定数を、固定端 $\varphi= \pm \phi_{0}$ での計 6 個の境 界条件、 $\mathrm{W}\left(-\phi_{0}\right)=\mathrm{W}^{\prime}\left(-\phi_{0}\right)=\mathrm{V}\left(-\phi_{0}\right)=0 、 \mathrm{~W}\left(\phi_{0}\right)=\mathrm{W}^{\prime}\left(\phi_{0}\right)=$ $\mathrm{V}\left(\phi_{0}\right)=0$ により決定する。

なお、対称性を考慮して固定端の 1 つに代えて、中央点 $\phi_{0}=0$ で の境界条件 (応力境界) を用いるほうが、未定定数決定のための連立 方程式の数が減る点で有利である。これは、付録からも確認される。

\section{6 変断面円弧アーチに作用する荷重}

(1) 厚肉シェル自重 (thick shell self-weight)

$$
\begin{aligned}
& p_{\varphi}(\varphi)=\alpha \gamma r t_{a} \sin (\varphi) \\
& p_{z}(\varphi)=\alpha \gamma(-r) t_{a} \cos (\varphi)
\end{aligned}
$$

(2) 薄肉シェル自重による作用力 (due to thin shell self-weight)

$$
p_{\varphi}(\varphi)=\alpha k \gamma r t_{b} \sin (\varphi)\left(6 \cos (\varphi)-4 \cos \left(\phi_{0}\right)\right), p_{z}(\varphi)=0
$$

(3) 厚肉シェル地震力 (thick shell earthquake)

$$
p_{\varphi}(\varphi)=\alpha \gamma r t_{a} \cos (\varphi) 、 p_{z}(\varphi)=\alpha \gamma r t_{a} \sin (\varphi)
$$

(4) 薄肉シェル地震力による作用力 (due to thin shell earthquake)

$$
\begin{aligned}
& p_{\varphi}(\varphi)=-\alpha k \gamma r t_{b}\left(4 \cos (\varphi) \cos \left(\phi_{0}\right)+2 \sin ^{2}(\varphi)-4 \cos ^{2}(\varphi)\right) \\
& p_{z}(\varphi)=0 \\
& \text { 全体シェルは、 } y \text { 軸に対して対称であり、上記薄肉シェルからの }
\end{aligned}
$$
母線方向作用力も対称なので、対称軸（ $y$ 軸）上で釣り合っているた め、母線方向の力の流れは無視する。

\section{7 変断面円弧アーチの各荷重ごとの応力と変形}

4.6 項の荷重ケースごとに、4.5 項の手順で計算されて得られた、 $\mathrm{N}(\varphi) 、 \mathrm{M}(\varphi) 、 \mathrm{~W}(\varphi) 、 \mathrm{~V}(\varphi)$ を、荷重ケース $(1)(2):$ Fig.5〜Fig.8に、 荷重ケース (3)(4) : Fig.9〜Fig.12に、 $\varphi \leq 0$ と $\varphi \geq 0$ に分けて（縦 軸の単位は図中記入) 示す。図化にあたっては、 $\phi_{0}=\pi / 2, \pi / 3$ の 2 ケースについて、それぞれ細線、太線で、 $k$ を 0 から 1 まで 0.2 きざ みでプロットする。ただし、 $\phi_{0}=\pi / 3$ の変位は、 10 倍（図中に $\times$ 10 と表記）して、 $\phi_{0}=\pi / 2$ の変位に重亦書きする。

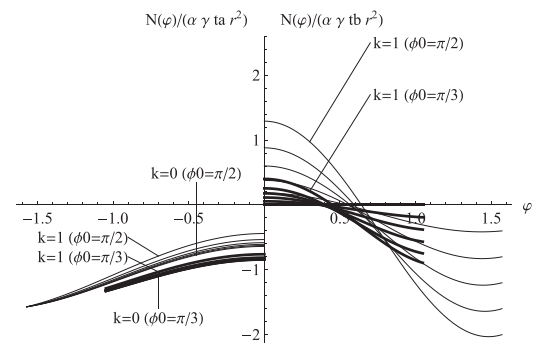

Fig.5 $N(\varphi)$ S.W.(L : thick shell s.w. ,R : due to thin shell s.w.)

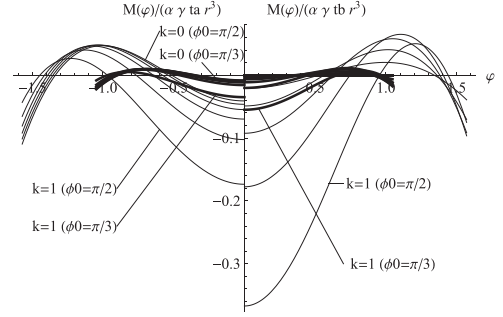

Fig.6 $M(\varphi)$ S.W.(L : thick shell s.w. ,R : due to thin shell s.w.)

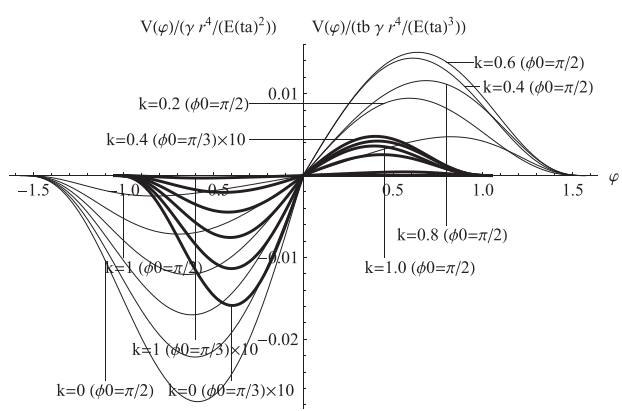

Fig.7 V $(\varphi)$ S.W.(L : thick shell s.w. ,R : due to thin shell s.w.)

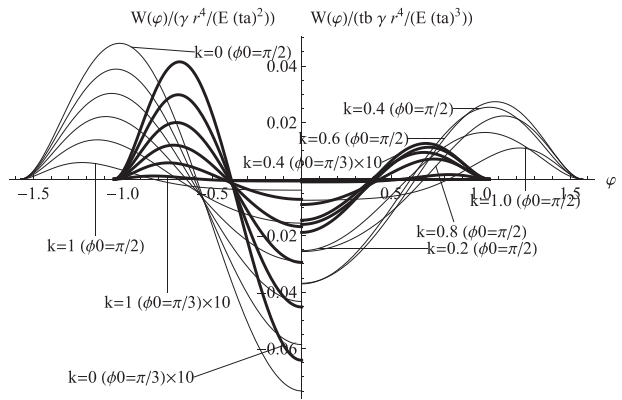

Fig.8 W $(\varphi)$ S.W.(L : thick shell s.w. ,R : due to thin shell s.w.)

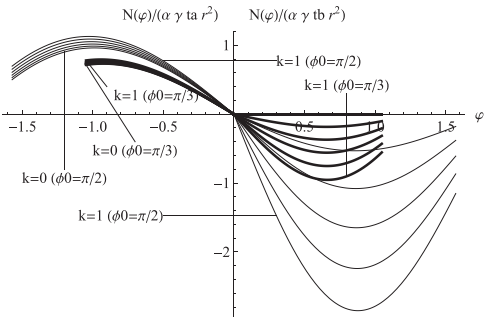

Fig.9 N( $\varphi$ ) E.Q.(L : thick shell e.q. , R : due to thin shell e.q.)

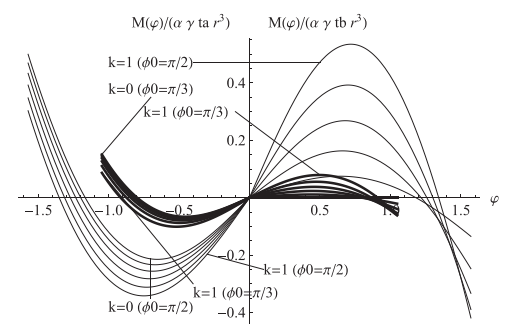

Fig.10 $M(\varphi)$ E.Q.(L : thick shell e.q. ,R : due to thin shell e.q.) 


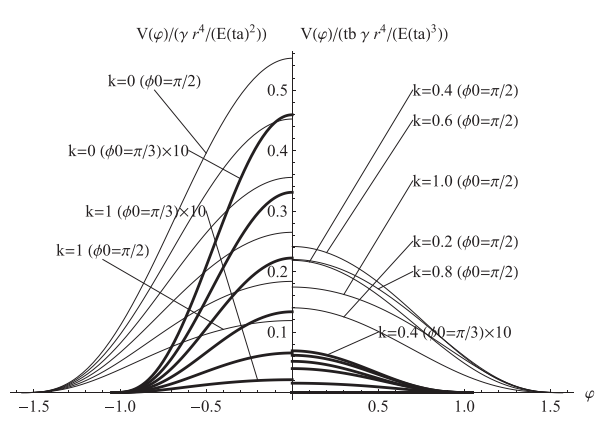

Fig.11 $V(\varphi)$ E.Q.(L : thick shell e.q. , R : due to thin shell e.q.)

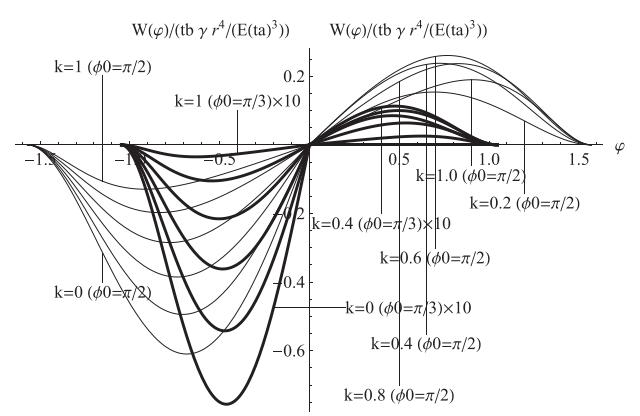

Fig.12 W $(\varphi)$ E.Q.(L : thick shell e.q. ,R : due to thin shell e.q.)

\section{5 連続解析}

5. 1 薄肉片持ち（膜応力） シェルの応力

薄肉片持ちシェルの応力は、変断面アーチの解析に先立って、 3.2 項に示す方法で単独に得られる。

変断面アーチの応力と対比できる応力は、円弧方向軸力 $N \varphi$ のみ であり、(6) 式から得られる值を厚み $t_{b}$ で除して応力度 $\sigma_{\varphi m e m}$ に 代え、さらに $\gamma r$ で除して無次元化すると、以下となる。

（自重） $\sigma_{\varphi m e m} /(\gamma r)=-\cos (\varphi)$

(地震） $\sigma_{\varphi m e m} /(\gamma r)=\sin (\varphi)$

変断面アーチ応力との比較のため、これらを次項 5.2 の無次元化し たアーチの直応力 $\sigma_{n}$ を示す Fig.13に、一点鎖線で重亦書きした。

\section{2 統合荷重による変断面円弧アーチの応力と変形}

4.7 項の結果をシェル板厚関係式 $t_{a} / t_{b}=\left(2 k \sin \left(\phi_{0}\right)\right) / \phi_{0}-$ $6 k \cos \left(\phi_{0}\right)+4 \quad$ (A) により統合し図化する。

板厚 $t_{a}$ は板厚 $t_{b}$ で表す。また、直応力 $N$ に代えて、 $N$ を断面積 $A=\alpha r t_{a}$ で除した、軸方向応力 $\sigma_{n}$ を用い、曲げモーメント $M$ に代えて、 $M$ を断面係数 $Z(\varphi)=\alpha r\left(t_{a}\right)^{2} / 6(1-k \cos (\varphi))$ で除し た、曲げ縁応力 $f_{b n}$ を用いる。

前項の $\sigma_{\varphi m e m}$ と本項の $\sigma_{n}$ は、パターンは反転的であるが、最大 絶対值の違いは $1.0 \sim 1.5$ 倍程度である。

統合の結果 Fig.13に $\sigma_{n}$ 、Fig14 $f_{b n} 、$ Fig.15にV、Fig.16に W、Fig.17 に変形図を、自重と地震を $\varphi \leq 0$ と $\varphi \geq 0$ に分けて示 す。重ね合わせた共通の目盛りを読みやすくするため、グラフには 適宜（図中に「×10」などで示す）倍率をかけている。

変形図は無次元化した $\mathrm{V}, \mathrm{W}$ の值に変形倍率をかけて、単位円上 にプロットしたものである。

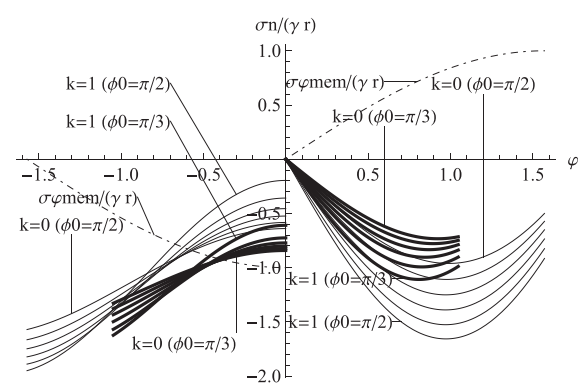

Fig.13 $\sigma_{n} /\left(\begin{array}{ll}\gamma & \mathrm{r}\end{array}\right)(\mathrm{L}: \mathrm{S} . \mathrm{W} ., \mathrm{R}:$ E.Q.) $\mathrm{fb} /\left((\gamma / \mathrm{tb}) r^{2}\right)$

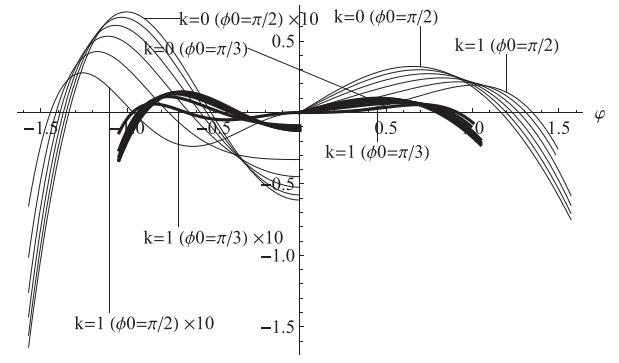

Fig.14 $f_{b n} /\left(\left(\gamma / t_{b}\right) r^{2}\right)$ (L : S.W. , R : E.Q.)

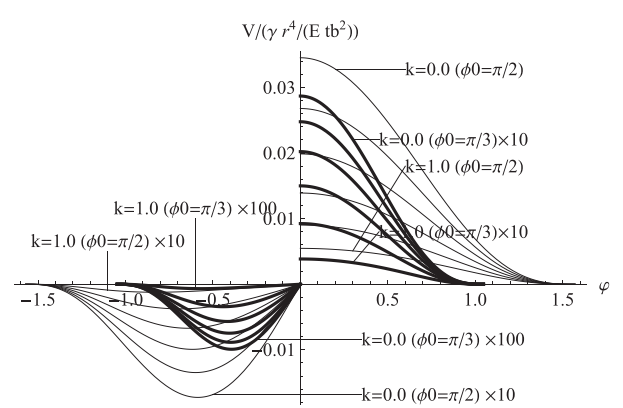

Fig.15 V/( $\left.\gamma r^{4} /\left(\mathrm{E} t_{b}^{2}\right)\right)$ (L: S.W. ,R : E.Q.)

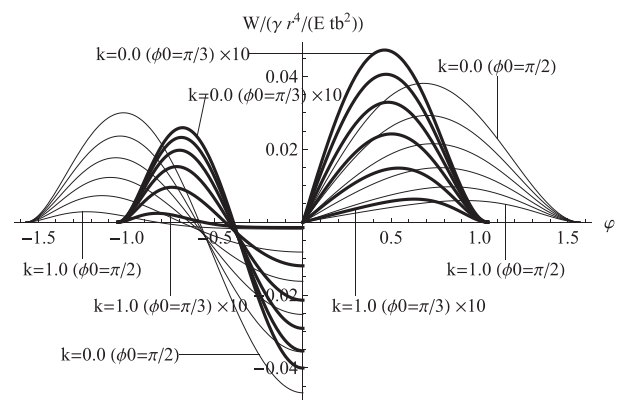

Fig.16 W/( $\left.\gamma r^{4} /\left(\mathrm{E} t_{b}^{2}\right)\right) \quad(\mathrm{L}: \mathrm{S} . \mathrm{W} .$, R : E.Q. $)$

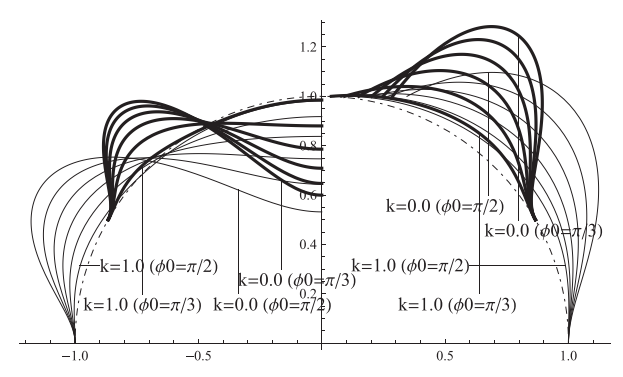

Fig.17 Deformation (L : S.W. ,R : E.Q.) 


\section{3 変断面円弧アーチ統合解析結果の考察}

(1) 仮定の検証 : 領域分割や板厚集約の程度を表すパラメーター $k$ の 変化に従って、すべての応力と変形が滑らかで単調な（極值がない） 変化をしていることが見て取れる。このことは、 4.1 項で示した厚肉 シェル領域を円弧アーチと仮定した際の $0<k<1$ の補間性に問題 がなく、その仮定が妥当であることを示している。

(2) 変形 $: \mathrm{W} 、 \mathrm{~V}$ は、 $k$ の刻みの順にほぼ等間隔で変化し、 $k$ が $0 \sim 1$ と増大するにつれて, $1 / 10$ 程度にまで段階的に小さくなる。なお、 $\mathrm{V} 、 \mathrm{~W}$ は、開角 $\phi_{0}$ に対しては、 $\phi_{0}$ が小さいと変形も小さくなり、 $\phi_{0}=\pi / 3$ での変位は $\phi_{0}=\pi / 2$ での変位の $1 / 10$ である。

(3) 応力: 直応力 $\sigma_{n}$ や曲げ縁応力 $f_{b n}$ は、 $k$ が $0 \sim 1$ と増大するに つれて、間隔を少しずつ広げながらも刻みの順は変えずに滑らかに 変化する。 $\sigma_{n}$ は不動点を持つパターンのまま変化するが、 $f_{b n}$ はパ ターンを $\varphi$ 方向に伸ばしながら、変化する。 $\sigma_{n}$ の絶対值最大は、 $k$ が大きくなるにつれて大きくなり、 $k=1$ では $k=0$ の 1.5 倍（地 震) となるが、 $f_{b n}$ は逆に $k$ が大きくなるにつれて絶対值最大は小さ くなり、 $k=1$ では $k=0$ の $1 / 3$ (地震) となる。図の縦軸から明ら かなように、応力でクリティカルなのは、 $\sigma_{n}$ でなくて $f_{b n}$ である。

(4) 板厚集約の効果 : 薄肉 ・厚肉シェルの面積比率に関与する $k$ は、 板厚集約の程度を示す指標であり、 $k$ が大きくなるほど、変形・応力 という構造的な有利性は明白に増す。

\section{4 薄肉片持ち（膜応力）シェルの変形}

薄肉片持ちシェルの変形は、 3.3 項に示したように、単独に膜応力 理論で得られた変位を、 5.2 項で得られた変断面アーチの変位に付け 加えることによって得られる。

変断面アーチの変位との対比のため、円弧方向変位 $v$ と法線方向 変位 $w$ を、図化して示す。図化にあたっては、

a) 薄肉シェル膜応力状態では重量と剛性がともに厚さ $t_{b}$ 比例す るため、変位は $t_{b}$ を含まない。 $t_{b}$ を含むアーチの変位を足し合わせ るためには $t_{b}$ の具体的な值が必要となり、 $t_{b}=r / 200$ とする。

b) 変形に対する $\alpha$ の影響はなく、 $\phi_{0}$ は変形の絶対值には影響し てもパターンへの影響は少ないことから、ここでは、典型的かつ包 括的な例として $\alpha=1 、 \phi_{0}=\pi / 2$ の場合を考える。

c) 内部境界曲線上の変位 $V_{b}$ や $W_{b}$ を太線で、自由境界上の変位 $V_{e}$ や $W_{e}$ を細線で, $k$ を 0.2. 刻みで変化させてプロットし、薄肉 シェル膜応力領域を網掛けする。ここに、内部境界曲線上の変位 $V_{b}$ と $W_{b}$ は、各々 4.3 項で用いた変断面アーチの変位 $V(\varphi)$ と $W(\varphi)$ と同值であり、自由境界上の変位 $V_{e} 、 W_{e}$ は、 3.3 項の膜応力状態の 変位 $v_{0}(x, \varphi) 、 w_{0}(x, \varphi)$ を使って、以下となる。

$V_{e}=v_{0}(\alpha r(1+k \cos (\varphi)), \varphi)+V(\varphi)$

$W_{e}=w_{0}(\alpha r(1+k \cos (\varphi)), \varphi)-w_{0}(\alpha r(1-k \cos (\varphi)), \varphi)+W(\varphi)$

自重による $V_{b} \sim V_{e}$ を Fig.18、 $W_{b} \sim W_{e}$ を Fig..19に、地震によ る $V_{b} \sim V_{e}$ を Fig.20、地震による $W_{b} \sim W_{e}$ を Fig.21に示す。

また、(28) 式の第 2 項を無視した、理想的に支持された場合の先 端変位 $W_{e i}$ を、一点鎖線にて Fig.19 と Fig. 21 に付け加える。

$k=0$ では、すべて厚肉シェル領域なので $V_{b} 、 W_{b}$ のみを記した。
Fig.18～Fig.21 から、以下のことが考察される。

(1) 薄肉シェル領域の膜応力変位 $v_{0} 、 w_{0}$ は、それぞれ $V_{b} 、 W_{b}$ より ピークが中央に少し寄っているがパターンは似ているので、薄肉、 厚肉に関わらず、シェル全体として滑らかに変形する。

(2) 自重では、 $k=0.8 \sim 1.0$ での内部境界曲線上の変位 (変断面 アーチの変位）は小さいが、薄肉シェルの変位は大きいので、先端 変位 $V_{e}$ や $W_{e}$ は $k=0$ の場合の $1 / 3$ 程度となる。一方、地震荷重 では、薄肉シェルの変位は相対的に小さく、アーチの変形で全体変 形が決まる。

(3) 理想的に支持された場合の先端変位 $W_{e i}$ と実際の変位 $W_{e}$ の差

は、全体変形から見れば、無視できるほどに小さい。

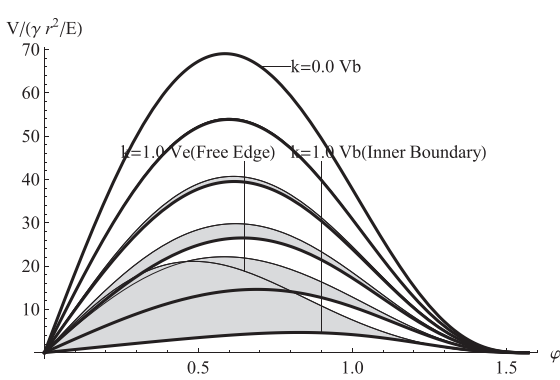

Fig.18 $V_{b} \sim V_{e} /\left(\gamma r^{2} /\right.$ E $)($ self-weight)

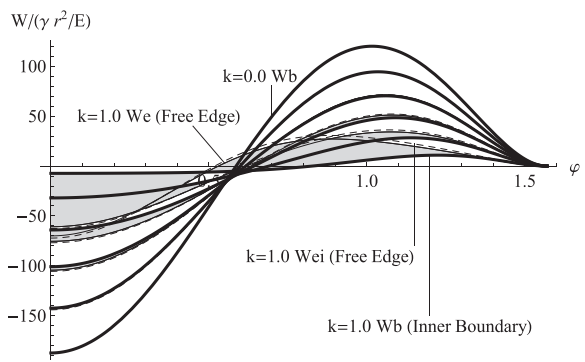

Fig.19 $W_{b} \sim W_{e}, W_{e i} /\left(\gamma r^{2} /\right.$ E ) (self-weight)

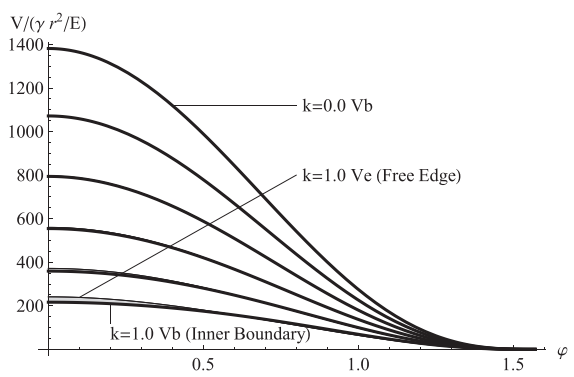

Fig.20 $V_{b} \sim V_{e} /\left(\gamma r^{2} /\right.$ E $)$ earthquake $)$

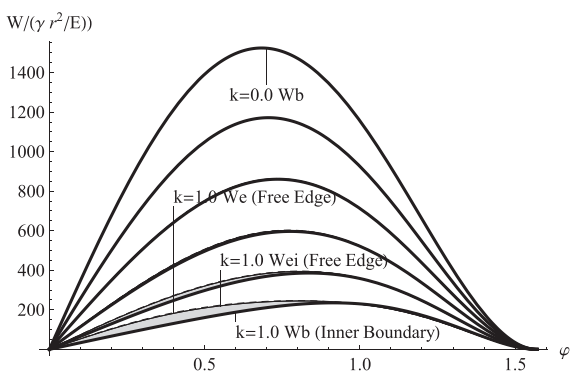

Fig.21 $W_{b} \sim W_{e}, W_{e i} /\left(\gamma r^{2} /\right.$ E ) (earthquake) 


\section{6 有限要素解析}

\section{1 有限要素解析の概要}

前章までの微分方程式による解析の結果から、典型的な例題とし て、 $\alpha=1 、 \phi_{0}=\pi / 2 、 k=0.8$ を採り、半径 $r=20 m$ 、薄肉シェ ルの厚み $t_{b}=0.11 \mathrm{~m}$ を用い、シェル板厚関係は $(\mathrm{A})$ 式より $t_{a}$ は $0.55 \mathrm{~m}$ として、自重に対する数值解析を行う。

数值解析には既報 ${ }^{8)}$ に示す筆者開発の円筒シェルに特化した有限 要素法（ガラーキン法と同等の、直接変分法による全ポテンシャル エネルギー停留から導びいた弱形式に、面内・面外の変形を表現で きる要素を適用したもの）を用いる。ただし、ひずみ一変位関係式 は厚肉シェルに拡張した以下とする。

$\epsilon_{x}=u^{(1,0)}(x, \varphi)-z w^{(2,0)}(x, \varphi)$

$\epsilon_{\varphi}=-\frac{z w^{(0,2)}(x, \varphi)}{r^{2}}+\frac{v^{(0,1)}(x, \varphi)}{r}+\frac{w(x, \varphi)}{r}+(* 1)$

$\gamma_{\varphi, x}=\frac{u^{(0,1)}(x, \varphi)}{r}-\frac{2 z w^{(1,1)}(x, \varphi)}{r}+v^{(1,0)}(x, \varphi)+(* 2)$

$(* 1)=-\frac{z w}{r^{2}}+\left(\frac{z}{r}\right)^{2}\left(\frac{w^{(0,2)}(x, \varphi)}{r}+\frac{w(x, \varphi)}{r}\right)$

$(* 2)=-\frac{z}{r}\left(-v^{(1,0)}(x, \varphi)+\frac{u^{(0,1)}(x, \varphi)}{r}\right)+\left(\frac{z}{r}\right)^{2}\left(\frac{u^{(0,1)}(x, \varphi)}{r}+w^{(1,1)}(x, \varphi)\right)$

$\left({ }^{*} 1\right)$ および $(* 2)$ の項を無視すれば、薄肉を仮定した Donnell 式 となり、既報 ${ }^{8)}$ 同様にこれを薄肉シェル領域に適用する。しかし、 厚肉シェル領域には、薄肉の仮定が成立しないので、 $\left({ }^{*} 1\right)$ および $(* 2)$ の項を考慮した Flügge 式 7$)$ を用いる。厚肉シェルの厚みは $t=t_{a} /(1-k \cos (\varphi))$ と表され、 $\varphi$ の関数であるが、各々の厚肉 シェル要素の板厚は図心位置での厚みとする。

解析モデルは、ともに対称性考慮の一体モデルとアーチ（厚肉シェ ル領域）モデルとし、要素分割は Fig.22 及び Fig.23 に示す。
Arch Model

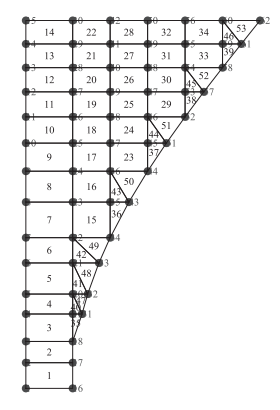

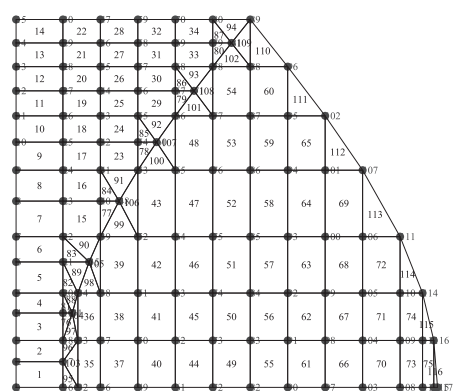

Total Model
Fig.22 Finite elements on $x-y$ plane

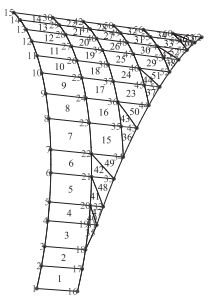

Arch Model

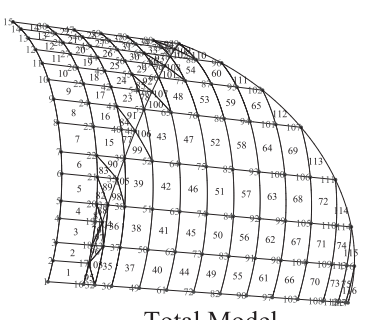

Total Model
Fig.23 Finite elements on 3D space

\section{2 有限要素解析結果}

FEM 一体解析の結果を $0<\varphi$ に実線で、アーチ（厚肉シェル領 域）FEM 解析と片持ちシェル領域の膜応力解を組み合わせたもの （改良理論解と呼ぶ）を $\varphi<0$ に実線で、前章の連続理論解の結果を $\varphi<0$ に破線で示す。また、厚肉シェル領域には太線を、薄肉シェ ル領域には細線を使う。内部境界上の応力は、一点鎖線で表す。

変形、応力とも、 $y$ 軸方向要素分割ライン上でのプロットを重㸚合 わせて表現する。分割ピッチは中央から外に向けて $4 m \sim 0.8 m \sim$ $2.4 m \sim 8 \times 3.2 m \sim 1.92 m \sim 0.96 m \sim 0.32 m$ である。変形 $(\mathrm{u}, \mathrm{v}, \mathrm{w})$ を Fig.24 Fig.26に、応力 $\left(\sigma_{x}, \sigma_{y}, \tau_{x y}, f_{b y}\right)$ を、Fig.27 Fig.30に 示す。ただし、容易な比較、判別のため、Fig.29、Fig.30では理論 解を $\varphi>0$ に延長し、Fig.30の厚肉シェル領域の $f_{b y}$ は、描線の重 複による見づらさを避けるため、細線とする。

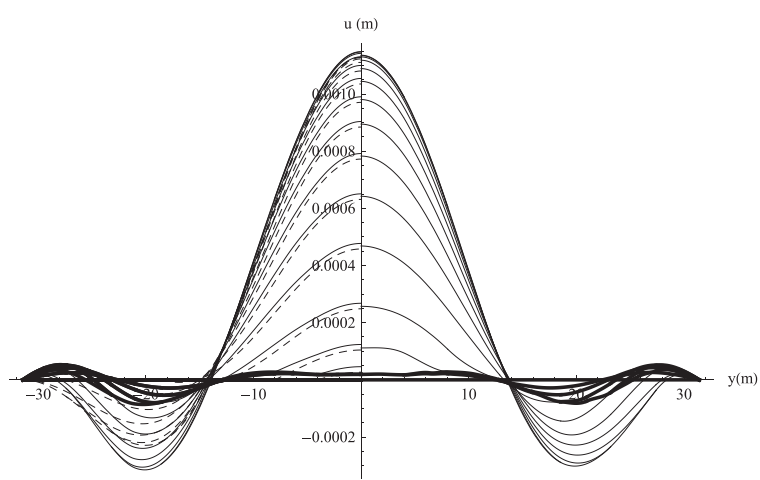

Fig.24 u (m) (L : Modified Theory \& Theory, R : FEM)

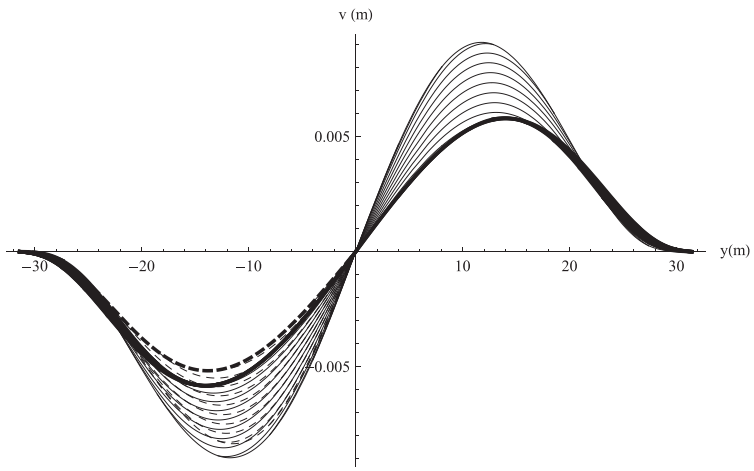

Fig.25 $\vee(m)$ (L: Modified Theory \& Theory ,R : FEM)

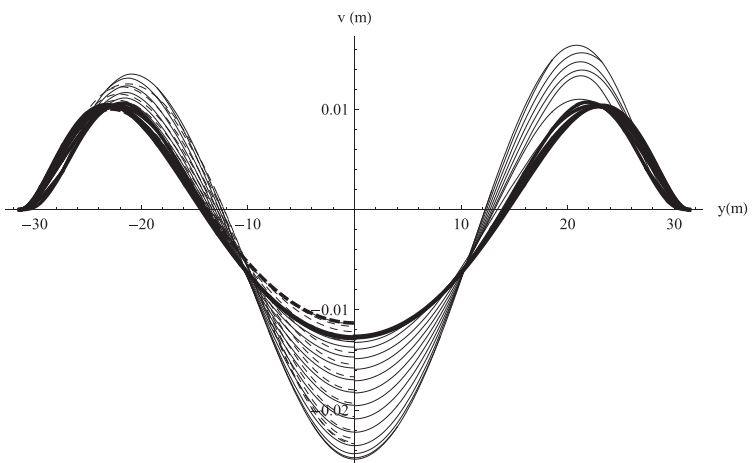

Fig.26 w (m) (L : Modified Theory \& Theory , R : FEM) 


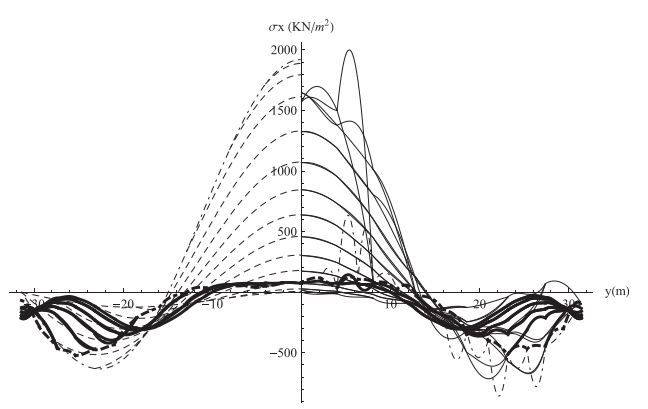

Fig.27 $\sigma_{x}\left(K N / m^{2}\right)(\mathrm{L}:$ Modified Theory \& Theory, R : FEM $)$

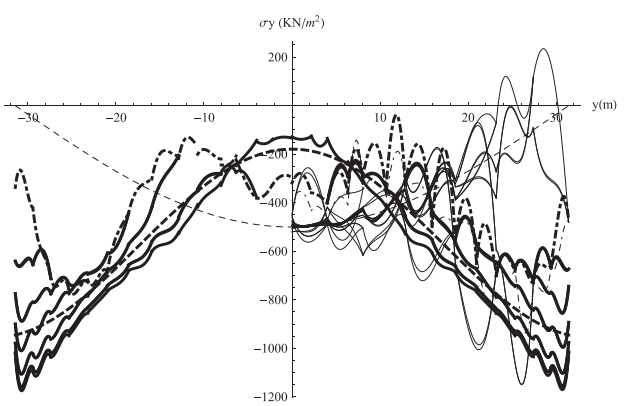

Fig.28 $\sigma_{y}\left(K N / m^{2}\right)(\mathrm{L}:$ Modified Theory \& Theory , R : FEM)

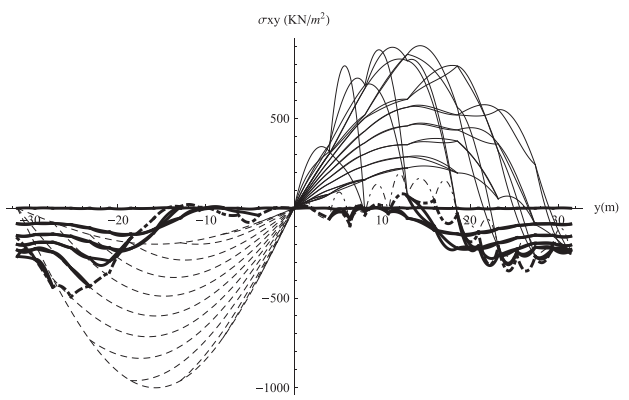

Fig.29 $\tau_{x y}\left(K N / m^{2}\right)(\mathrm{L}:$ Modified Theory \& Theory , R : FEM)

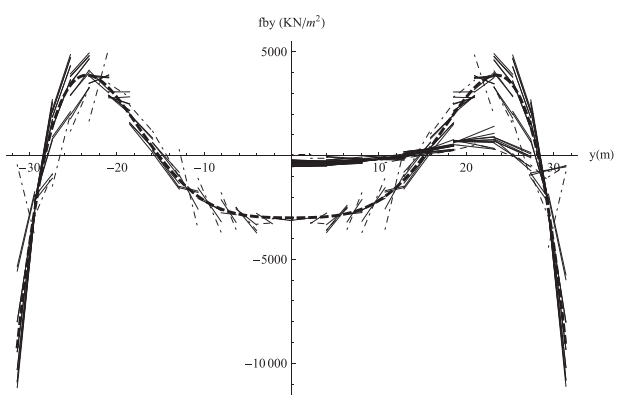

Fig.30 $f_{b y}\left(K N / m^{2}\right)(\mathrm{L}:$ Modified Theory \& Theory , R : FEM)

\section{3 解析結果の考察}

(1)FEM 一体解析の厚肉シェル領域と厚肉シェル領域だけを取り出 した FEM 解析の結果は、よく一致している。

(2)FEM 一体解析の厚肉シェル領域は、変形 V、W が $10 \%$ 程度大 きいこと以外は、母線方向の変形を無視したアーチ理論解ともょく 一致しており、同じく薄肉シェル領域の応力・変形は、大きな板厚 差がある内部境界付近での乱れを除けば、理論解（膜応力解）とよ く一致している。
7 まとめ

(1) 円弧方向曲線自由端－母線方向境界固定の部分円筒シェルが、固 定境界端点より発する一対の内湾曲線（内部境界曲線）によって、 内部の厚肉シェルと両外部の薄肉シェルに分割される場合、分割形 状と板厚についての簡単な例として 2.1 項 a) c) に示すような適切

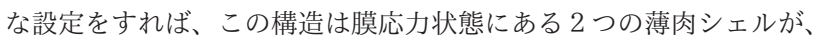
変断面の円弧アーチとしての厚肉シェルに片持ち支持される連続構 造であり、膜応力理論とアーチ理論の連続的な適用により、応力・変 形が直接的に求められることを示した。

(2) 円筒シェルの一般式 (Flügge 理論) から母線方向の次元を消去 し、修正を加えて、変断面円弧アーチの理論式を誘導し、変断面（断 面性能が円弧方向変数の関数）を考慮した、連立常微分方程式から なる理論式の解法と手順を示した。

(3) 既報 ${ }^{8)}$ の薄肉片持ち膜応力理論と上記変断面アーチ理論には、 円弧方向変位 $\mathrm{V}$-法線方向変位 $\mathrm{W}$ 関係式に類似性があり、これに より、内部境界曲線上での変位の連続性が保証されることを、数式 と図を用いて示した。

(4) シェル展開平面での平均板厚一定（材料使用量条件一定）のも と、水平投影形状が矩形のものから極端な跳㸚出しを持つものまで の幅広い形状を包括するパラメーターを保持したまま、自重・地震 荷重について理論式を解き、パラメトリックな検討から、設定の妥 当性と板厚集約による構造的な有利性ひいては経済性を確認した。

(5) 例題による FEM 解析を行い、薄肉、厚肉シェル間の相互作用が 少なく、理論解（連続解析）と結果がよく一致することを確認した。

\section{謝辞}

本論文を䌂めるにあたり、京都大学大崎純教授には、論旨整理への 貴重な助言と原稿に対する多くの的確な指摘をいただきました。深 く感謝いたします。また、論文末尾に添付の英文要約について、京 都大学野中泰二郎名誉教授には、懇切丁寧な多くの助言を頂きまし た。深く感謝いたします。

参考文献

1) 米国土木学会編（横尾他 共訳）: 円筒シャーレの設計 丸善 1955

2) 坪井善勝 : 曲面構造 シェルの理論とその応用 丸善 1965

3) Timoshenko,S. and Woinowsky,K.S.:Theory of Plates and Shells second edition McGraw-Hill Book Company 1987

4) Uchiyama,K.and Yamada,S.:Theoretical Studies of the Buckling and Nonlinear Deflection Behavior of Clamped Partial Circular Cylindrical Shells under External Pressure 日本建築学会構造系論 文報告集，第 364 号，pp.80 90，1986.6

5) 皆川洋一 : 水平梁を有する鉄筋コンクリート造円筒シェル屋根の終局 耐力 直交異方性円筒シェル屋根の解析と終局耐力評価式 日本建築学会構造系論文報告集，第 451 号，pp.111～121，1993.9

6) Timoshenko,S. and GereJ.M.:Theory of Elastic Stability second edition McGraw-Hill Book Company 1961

7) 日本機械学会編 : シェルの振動と座屈ハンドブック 技報堂出版 2003

8) 高垣利夫 : 円筒から切り出されたシェルの片持ち支持条件下における 膜応力的特徵 日本建築学会構造系論文集, 第 706 号, pp.1857 1867, 2014.12

9) Timoshenko,S. and GoodierJ.N.:Theory of Elasticiy third edition McGraw-Hill Book Company 1970

10) 田中弥寿雄，河野和間 : 円弧アーチ架構の一解法 日本建築学会論文報告集, 号外 40, p.178, 1965.9 
付録＼cjkstart直径に沿って向かい合う集中荷重を受けるリング

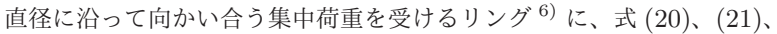
(22)、(23) からなる連立常微分方程式を適用して、4.5 項に示した手順に よっての解いたものと、このうちの (22) 式に替えて下記の (22') 式 (省略 のない Flugge 式）を用いたものとの比較を行い、結果を確認する。（概要 及び解析モデルを Fig. 31 に示す。)

$\frac{\mathrm{M}^{\prime}(\varphi)}{r^{2}}+\frac{\mathrm{N}^{\prime}(\varphi)}{r}+\mathrm{p} \varphi(\varphi)=0$

$\frac{\mathrm{M}^{\prime \prime}(\varphi)}{r^{2}}-\frac{\mathrm{N}(\varphi)}{r}+\mathrm{pz}(\varphi)=0$

$0=\frac{V^{\prime}(\varphi)}{r}+\frac{W(\varphi)}{r}$

$\mathrm{N}(\varphi)=\frac{\mathrm{E} t}{1-\nu^{2}}\left(\frac{t^{2}\left(W^{\prime \prime}(\varphi)+W(\varphi)\right)}{12 r^{3}}+\frac{V^{\prime}(\varphi)+W(\varphi)}{r}\right)$

$\mathrm{M}(\varphi)=-\frac{\mathrm{E} t^{3}}{12\left(1-\nu^{2}\right)}\left(\frac{W^{\prime \prime}(\varphi)}{r^{2}}+\frac{W(\varphi)}{r^{2}}\right)$

1) 式 $(20) 、(21)$ は中間荷重が無いので、 $\mathrm{p} \varphi(\varphi) 、 \mathrm{pz}(\varphi)$ の項を 0 とすれ ば、その解は未定定数 $\mathrm{C} 1, \mathrm{C} 2, \mathrm{C} 3$ を含む、下式 (a)、(b) である。

$\mathrm{N}(\varphi)=\mathrm{C} 1 \cos (\varphi)+\mathrm{C} 2 \sin (\varphi)$

$\mathrm{M}(\varphi)=-\mathrm{C} 1 r \cos (\varphi)-\mathrm{C} 2 r \sin (\varphi)+\mathrm{C} 3$

2) 境界条件 $\mathrm{M}^{\prime}(0)=0$ より、 $\mathrm{C} 2=0$ 、また $\varphi=\pi / 2$ での荷重とせん弾力 の釣り合いから、 $(1 / r) \mathrm{M}^{\prime}(\pi / 2)=-\mathrm{P} / 2$ より、 $\mathrm{C} 1=-\mathrm{P} / 2$ となり、式 $(\mathrm{c})$ のように $\mathrm{N}(\varphi)$ は確定し、 $\mathrm{M}(\varphi)$ は $\mathrm{C} 3$ のみを含む。

$\mathrm{N}(\varphi)=-\frac{1}{2} P \cos (\varphi), \quad \mathrm{M}(\varphi)=\mathrm{C} 3+\frac{1}{2} \operatorname{Pr} \cos (\varphi)$

$3)$ 式 (c) の $\mathrm{M}(\varphi)$ を式 $(27)$ に代入して $\mathrm{W}(\varphi)$ の 2 階の微分方程式を解け ば新たな積分定数 $\mathrm{C} 4 、 \mathrm{C} 5$ を含む解 $(\mathrm{d})$ を得る。

$\mathrm{W}(\varphi)=\frac{12 \mathrm{C} 3 r^{2}+3 \operatorname{Pr}^{3} \varphi \sin (\varphi)+3 \operatorname{Pr}^{3} \cos (\varphi)}{\left(\mathrm{E} /\left(-1+\nu^{2}\right)\right) t^{3}}$

$$
+\mathrm{C} 4 \cos (\varphi)+\mathrm{C} 5 \sin (\varphi)
$$

4) $\varphi=0, \varphi=\pi / 2$ での境界条件 $\mathrm{W}^{\prime}(0)=\mathrm{W}^{\prime}(\pi / 2)=0$ より、 $\mathrm{C} 4=0$ 、 $\mathrm{C} 5=0$ となり、結局 $\mathrm{W}(\varphi)$ は式 $(\mathrm{d})$ 右辺の最後の 2 項を捨てた式 $(\mathrm{e})$ に なる。

$\mathrm{W}(\varphi)=\frac{12 \mathrm{C} 3 r^{2}+3 \operatorname{Pr}^{3} \varphi \sin (\varphi)+3 \operatorname{Pr}^{3} \cos (\varphi)}{\left(\mathrm{E} /\left(-1+\nu^{2}\right)\right) t^{3}}$

5) これを式 $(22)$ に代入して積分すれば、 $\mathrm{V}(\varphi)$ が新たな積分定数 C6 含んで下記となる。

$\mathrm{V}(\varphi)=\mathrm{C} 6-\frac{3 r^{2}\left(4 \mathrm{C} 3 \varphi-\operatorname{Pr} \varphi \cos (\varphi)+2 \operatorname{Pr} \sin \left(\frac{y}{r}\right)\right)}{\left(\mathrm{E} /\left(-1+\nu^{2}\right)\right) t^{3}}$

6) $\varphi=0, \varphi=\pi / 2$ での対称性から $\mathrm{V}(0)=\mathrm{V}(\pi / 2)=0$ より、C6=0、 $C 3=-P r / \pi$ と末定係数すべてが定まり、 $\mathrm{M}(\varphi) 、 \mathrm{~W}(\varphi) 、 \mathrm{~V}(\varphi)$ は以下と なる。

$\mathrm{M}(\varphi)=\operatorname{Pr}\left(\frac{\cos (\varphi)}{2}-\frac{1}{\pi}\right)$

$\mathrm{W}(\varphi)=\frac{\operatorname{Pr}^{3}(-3 \varphi \sin (\varphi)-3 \cos (\varphi)+12 / \pi)}{\left(\mathrm{E} /\left(1-\nu^{2}\right)\right) t^{3}}$

$\mathrm{V}(\varphi)=\frac{3 \operatorname{Pr}^{3}(-4 \varphi / \pi+2 \sin (\varphi)-\varphi \cos (\varphi))}{\left(\mathrm{E} /\left(1-\nu^{2}\right)\right) t^{3}}$

式 $(22)$ に替えて式 $\left(22^{\prime}\right)$ を用いる場合でも、上記 1)～4) の過程は変わら ない。5) 以降は、以下の $\left.\left.5^{\prime}\right) \sim 6^{\prime}\right)$ に変わる。

$\left.5^{\prime}\right)$ 式 (e) と式 (c) の $\mathrm{N}(\varphi)=-\frac{1}{2} P \cos (\varphi)$ を式 $\left(22^{\prime}\right)$ に代入して積分す れば、 $\mathrm{V}(\varphi)$ が新たな積分定数 $\mathrm{C} 6$ を含んで下記となる。

$\mathrm{V}(\varphi)=\mathrm{C} 6-\frac{\left(\mathrm{C} 3 \varphi r^{2}\left(t^{2} / r^{2}+12\right)+6 \operatorname{Pr}^{3} \sin (\varphi)-3 \operatorname{Pr}^{3} \varphi \cos (\varphi)\right)}{\left(\mathrm{E} /\left(-1+\nu^{2}\right)\right) t^{3}}$

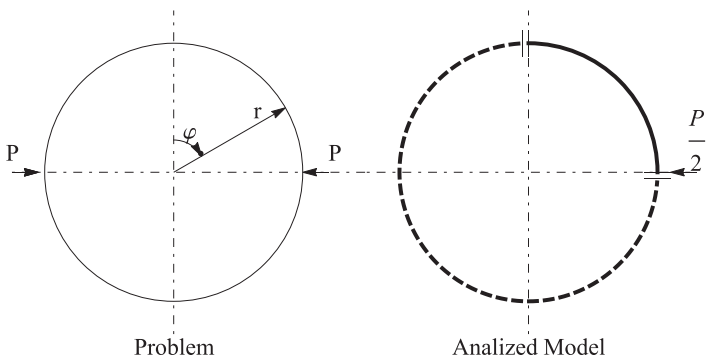

Fig.31 Example of a ring compressed by two opposite forces

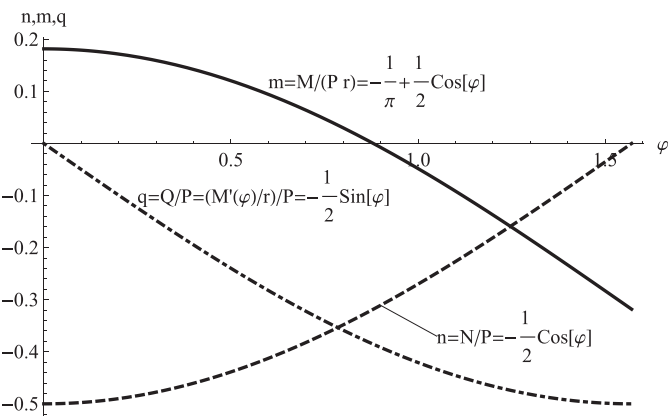

Fig.32 Non-dimensional $N, M, Q$

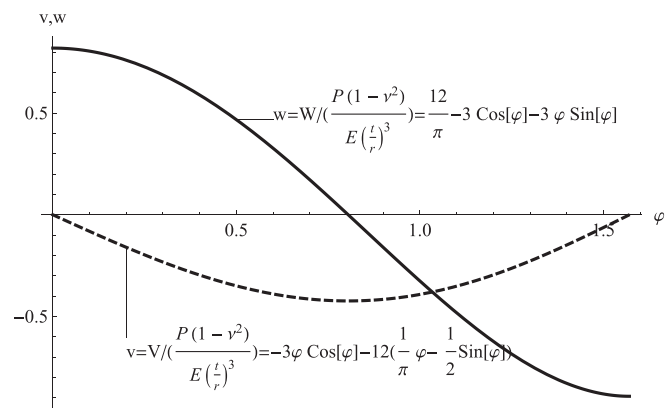

Fig.33 Non-dimensional $W, V$

6') $\varphi=0, \varphi=\pi / 2$ での対称性から $\mathrm{V}(0)=\mathrm{V}(\pi / 2)=0$ より、

$C 6=0, \quad C 3=-\frac{12 P r^{3}}{\pi\left(t^{2}+12 r^{2}\right)}$

と末定係数すべてが定まり、 $\mathrm{M}(\varphi) 、 \mathrm{~W}(\varphi) 、 \mathrm{~V}(\varphi)$ は以下となる。

$\mathrm{M}(\varphi)=\operatorname{Pr}\left(\frac{1}{2} \cos (\varphi)-\frac{1}{\pi\left(\frac{t^{2}}{12 r^{2}}+1\right)}\right)$

$\mathrm{W}(\varphi)=\frac{3\left(1-\nu^{2}\right) P r^{3}}{\mathrm{E} t^{3}}\left(\frac{4}{\pi\left(\frac{t^{2}}{12 r^{2}}+1\right)}-\varphi \sin (\varphi)-\cos (\varphi)\right)$

$\mathrm{V}(\varphi)=\frac{3 \operatorname{Pr}^{3}(-4 \varphi / \pi+2 \sin (\varphi)-\varphi \cos (\varphi))}{\left(\mathrm{E} /\left(1-\nu^{2}\right)\right) t^{3}}$

式 $(\mathrm{g})(\mathrm{h})(\mathrm{i})$ と式 $\left(\mathrm{g}^{\prime}\right)\left(\mathrm{h}^{\prime}\right)\left(\mathrm{i}^{\prime}\right)$ を比較すると、式 (i) と式 (i') はまったく同じ であり、式 $(\mathrm{g})(\mathrm{h})$ と式 $\left(\mathrm{g}^{\prime}\right)\left(\mathrm{h}^{\prime}\right)$ の違いは $(t / r)^{2} / 12 \ll 1$ と考えて $(t / r)^{2}$ の項を無視するかどうかであるが、無視することはシェルのプロポーション を考えれば問題はない。つまり、ここで採った簡略化は妥当であった。

Fig.32、Fig.33 に、応力と変形を無次元化して、数式とともに図示する。

以上 


\section{STRUCTURAL CHARACTERISTICS OF THE PARTIAL CIRCULAR CYLINDER PARTITIONED INTO THICK AND THIN SHELLS BY A PAIR OF CONCAVE CURVES}

Toshio TAKAGAKI*

* T.TAKAGAKI P.E.O.

In early days as in the 1940s, a partial cylindrical concrete shell (long shell) was frequently used as a barrel roof structure. Many detailed investigations have been carried out, since the advent of ASCE Manuals of Engineering Practice in 1952. As a result, it has been found difficult to realize a strict membrane stress field in the barrel-roof-type shell, because the number of stress unknowns is unfit for the number of available boundary conditions.

In a previous paper, the present author showed that a shell segment cut out from a circular cylinder with particular shapes and boundaries was able to satisfy the condition of membrane stress field. In this paper, a segment of partial circular cylinder is investigated, which is partitioned into three parts, by a pair of concave curves into the central thick shell zone with both fixed boundaries parallel to the generator, and two outer thin shell zones.

The left half of the circular shell segment under consideration is taken to be the mirror image of the right half, or vice versa.

Each of the left and right thin shell zones has shapes and boundaries that satisfy the requirement of a membrane stress state, in a way similar to the case in the previous paper. The central thick shell zone, on the other hand, behaves like an arch in which breadth and depth vary in the circular direction, keeping a constant cross-sectional area.

It is noted that similarity exists with regard to the differential equations which relate displacement (denoted as $\mathrm{V}$ ) in the circular direction with the displacements in the normal direction (denoted as W), between each circular cylinder in membrane stress states and the circular arch with a varied cross-section.

This fact assures continuity of displacements along the concave partition lines.

Thus, given a method of distributing suitable thickness to each shell zone, the outer thin shell zones in membrane stress states are cantilever-supported by the inner thick shell zone treated as an arch with varying cross-section along the circular direction.

After solving the outer thin shell zones by a membrane theory presented in the previous paper, and after introducing pertinent parameters to describe the adequate shell-thicknesses with related shell shape, the thick shell zone is analyzed by solving a set of differential equations on the basis of the arch theory led by eliminating the longitudinal distribution in the general shell theory on a circular cylinder (the Flügge's Theory), including these parameters.

The results of these parametric analyses are herein presented, and it is confirmed that the partial circular cylinder partitioned into a thick shell and two thin shells by a pair of concave curves can be solved as the Membrane Shell-Arch structure theoretically.

For comparison, a typical example is selected with consideration of the results of above parametric analyses, and is analyzed by the Finite Element Method of Weak Form, equivalent to the Galerkin Method, by minimizing directly the total potential energy of a general circular cylindrical shell in which finite elements are able to express not only membrane deformations, but also bending deformations.

This comparison with the FEM results indicates the adequacy of the proposed Membrane Shell-Arch Theory.

From another point of view, the method introduced here serves as a means of determining an economical thickness distribution, in the design of a shell roof to cover a large space. 